\title{
Creative industries, Investment trends and their impact on the Economy and Financial Sectors: A study from Vietnam
}

Phan The Conga, ${ }^{a}$ Thuongmai University, Hanoi, Vietnam, Email: acongpt@tmu.edu.vn

Creative industries have been seen to become increasingly important to economic well-being, with proponents suggesting that "human creativity is the ultimate economic resource," and that "the industries of the twenty-first century will depend increasingly on the generation of knowledge through creativity and innovation." The term creative industries, refers to a range of economic activities which are concerned with the generation or exploitation of knowledge and information. Development of creative industries will contribute to the awareness and protection of intellectual property rights and copyrights in the creative industry, in order to meet the WTO's requirements on intellectual property rights. Government support for creative industries will help create a healthy competitive environment for businesses in the industry. It is important for Vietnam's businesses to select a proper orientation and gain a suitable position in the global creative economy. The creative service sectors of great strength in Vietnam, which are also in need of investment are: design, art, education, tourism, performing arts, fashion, handicraft, culture, foods, and others. Additionally, empirical investigations in the present study reveal that creative industry indicators have a positive and significant influence on the economy and financial sectors. This study's findings are highly recommended to government officials, economists, and anyone else working to make strategic decisions to achieve better economic results.

Key words: Intellectual property rights; Creative Vietnam; Creative Economy; Creative industries; UNCTAD. 
International Journal of Innovation, Creativity and Change. www.ijicc.net

Volume 7, Issue 5, 2019

\section{Introduction and Background}

Globally, the need for change in the creation of property and power is ever-growing. While power was previously generated based on industries like mechanical engineering, manufacturing, chemistry, etc. it is currently built upon services, information and innovation. Definitions of a "creative economy" can be varied, but they generally agree on one point: the heart of a creative economy is creative industry. Although there is no universally agreed definition of "creative economy" or "creative industries", "creativity" seems to be considered the key concept. Creativity is currently understood as a major resource in the knowledge economy, which results in technological innovations, changes and competitive advantages in businesses and the national economy. Changes in creativity contribute to increasing both tangible and intangible products, these items are commonly called "creative goods and services", which then constitute creative industries. Creative industries are defined as a range of knowledge products, including: creativity, cultural and economic value, and market target. They include the cycles of creation, production and distribution of goods and services that use creativity and intellectual capital as primary inputs. Different models of creative economies may have different ways of identifying and classifying creative industries.

The important point is not the definition itself, but how to use the definition as a new approach to development strategy. According to the United Nations Conference on Trade and Development (UNCTAD, 2008), creative industries are cultural heritage, traditional cultural expressions, visual arts and performing arts, media including publishing and printed media, new media, design, and creative services including advertisements and architecture. The concept of creative industries is still developing and expanding. It is also becoming more clearly conceptualized and hopefully there will a new classification system, which will not be limited to convenient or available statistics, but will use new insights to find important data and build effective assessment criteria.

The term creative industries refers to a range of economic activities which are concerned with the generation or exploitation of knowledge and information. They may also be referred to as the cultural industries (especially in Europe (Hesmondhalgh 2002, p. 14)) or the creative economy (Howkins 2001). Most recently, they have been denominated as the Orange Economy in Latin America and the Caribbean (Buitrago \& Duque 2013). The creative industries have been seen to become increasingly important to economic well-being, with proponents suggesting that "human creativity is the ultimate economic resource" (Florida 2002 , p. xiii), and that "the industries of the twenty-first century will depend increasingly on the generation of knowledge through creativity and innovation" (Landry \& Bianchini 1995, p. 4). 
International Journal of Innovation, Creativity and Change. www.ijicc.net

Volume 7, Issue 5, 2019

According to UNCTAD (2008), creative industries contributed to $3.4 \%$ of international trade and increased by $8.7 \%$ from 2000-2005. As defined by UNESCO, creative industries include creative products in cultural and art areas. They originate from individual creativity, skills, and talents, that can potentially create property and jobs via intellectual property exploitation. The development of creative industries requires effective protection of intellectual property, and thus contributes to improving public awareness, and actual protection, of intellectual property/copyright of products in creative industries, to ultimately meet the WTO requirements on intellectual property. Government support for creative industries facilitates the formulation of a healthy environment between industrial businesses thanks to effective coordination between functional agencies in industry management and development support. Accordingly, industry databases are created to enable government management to catch up with the growth rates of industry participants. Creative industries generate added value through industrial products (industrial packaging design, industrial design, advertising media, etc.)

Figure 1. Top 10 creative goods exporters worldwide

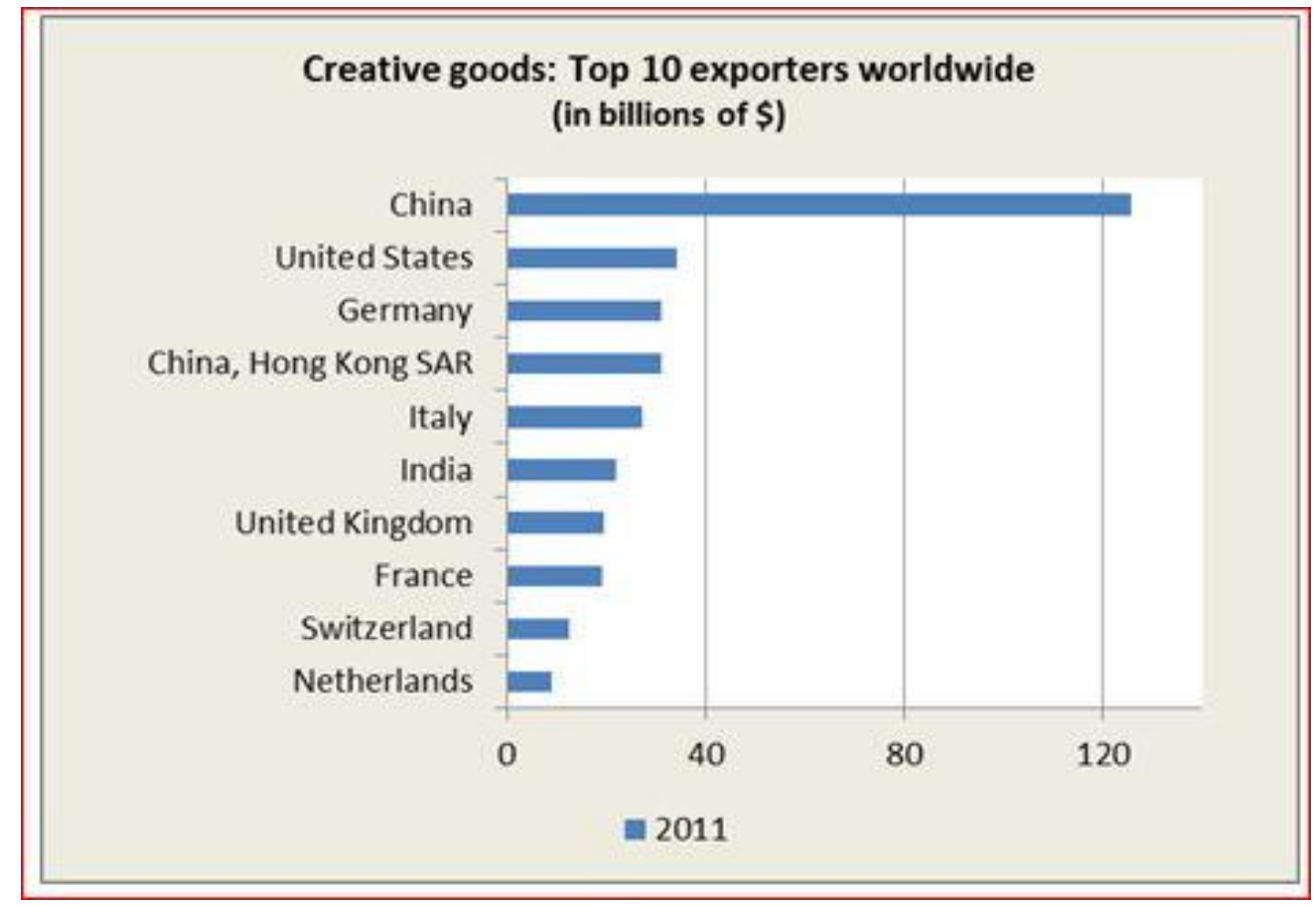

Source: UNCTAD, based on official data in UN COMTRADE database

According to UNCTAD (2010), creative industries can potentially integrate the development tendency of environmentally friendly products to create new product and service industries, such as fashion, ecotourism, and environmental communication programs. Creative industries create value which connect traditional and new cultural values. Also according to UNCTAD, commercializing creative products brings about measurable economic change in cultural 
International Journal of Innovation, Creativity and Change. www.ijicc.net

Volume 7, Issue 5, 2019

products, like in the music industry in Latin American countries. Therefore, traditional cultural values have an opportunity for preservation and development for future generations. Creative industries also bear training values when accelerating creativity and innovation for young labour forces. Studies show that creative industries contribute 2-8\% of the labour force every year and industry employees have relatively high satisfaction levels in comparison with other industries. Creative industries have become an essential part of the global economy, which has been developing rapidly in cross culture, business and technology. As of 2010, the commercial value of global creative industries is US $\$ 892$ billion.

The USA became the world's largest creative economy, and created a wonderful environment to develop a creative economy in. President Obama called for technology innovation to maintain its position and confirmed that creativity is the key to economic development. As the USA considers creative economies to be significant for economic development, it might be hard for any country to ignore the creative economy, if they are seeking prosperity.

Figure 2. World exports of Creative Goods in 2002-2011

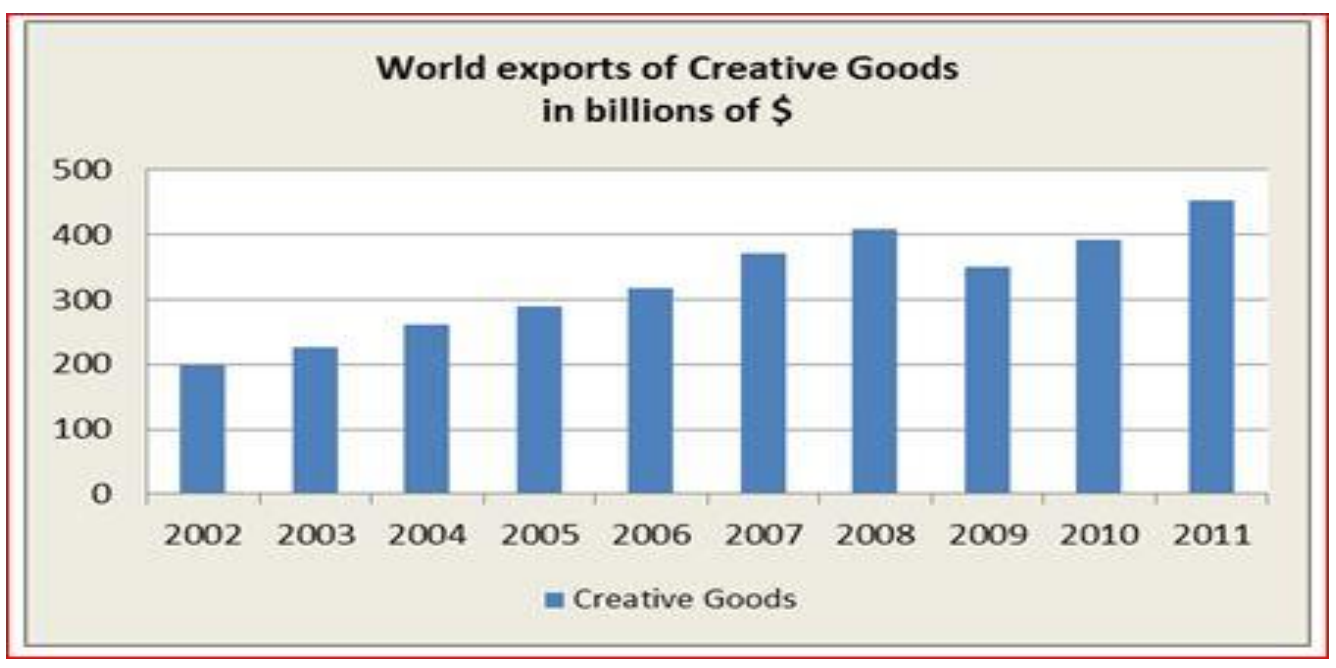

Source: UNCTAD, based on official data in UN COMTRADE database

The Thai government spent THB 20 billion (US\$667 million) to raise the contribution of the creative economy to GDB from $12 \%$ in 2010 to $20 \%$ in 2012. Thailand's government also selected 15 industrial goods groups to promote creative economy development, including handicraft, tourism, traditional medicine, food, performing arts, music, design, fashion, and architecture. Accordingly, the Thai government expects to turn the country into the creative industrial centre of South East Asia.

In this light of the above, creativity and innovation seem to be an irreversible tendency in economies and business across the world. While the profitability of financial capital, 
International Journal of Innovation, Creativity and Change. www.ijicc.net

Volume 7, Issue 5, 2019

machinery or physical labour is limited, the value of intellectual property and creativity is huge, making a breakthrough can be a decisive factor for a business's competitiveness. It is time for Vietnamese businesses' and the economy, to have a stronger and more comprehensive approach to initial idea flows of business creativity and innovation in the world. Vietnam faces a lot of challenges to sustain its' high economic growth rate. A study into Vietnam's economic growth scenarios by McKinsey Global Institute shows that Vietnam needs to raise its lab or productivity by $50 \%$ to sustain its' economic growth since its labour supply is falling sharply and the economic restructuring and urbanization pace is slowing down. This is not an easy scenario for Vietnam.

Figure 3. Contribution of creative industries to GDP

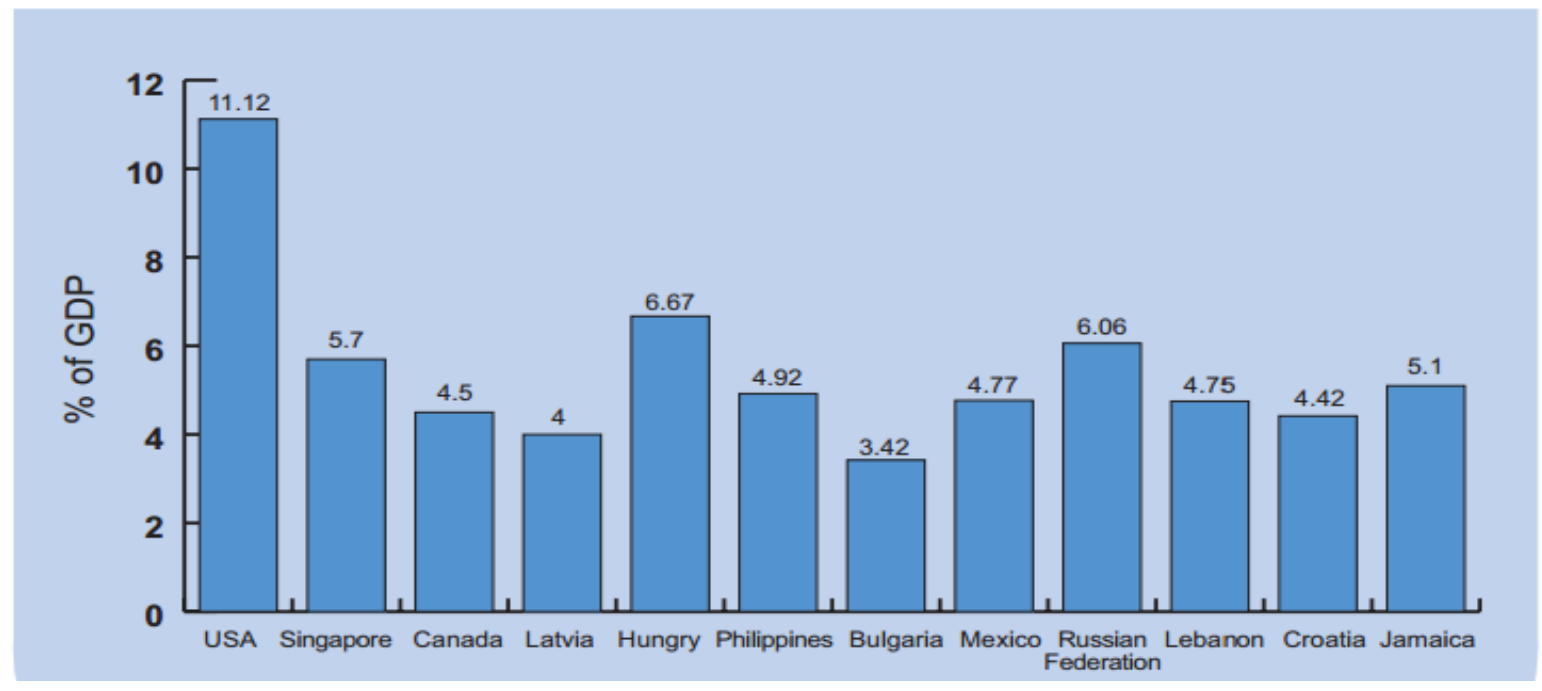

Source: UNCTAD, Creative Economy Report 2008

Globally, creative industries, excluding software and general scientific research and development, are said to have accounted for around $4 \%$ of the world's economic output in 1999, which is the last year for which comprehensive figures are currently available. Estimates of the output corresponding to scientific research and development suggest that an additional 4-9\% might be attributable to the sector if its definition is extended to include such activities, though the figures vary significantly between different countries. The complex supply chains in creative industries sometimes make it challenging to calculate accurate figures for the gross value added by each sub-sector. This is particularly the case for the service-focused sub-sectors such as advertising, whereas it is more straightforward in product-focused sub-sectors such as crafts. Not surprisingly, competition in product-focused areas tends to be more intense with a tendency to drive the production end of the supply chain to become a commodity business. There may be a tendency for publicly funded creative industries development services to inaccurately estimate the number of creative businesses during the mapping process. There is also imprecision in nearly all tax code systems that 
International Journal of Innovation, Creativity and Change. www.ijicc.net Volume 7, Issue 5, 2019

determine a person's profession, since many creative people operate simultaneously in multiple roles and jobs. Both these factors mean that official statistics relating to the creative industries should be treated with caution. A more entrepreneurial culture will have to take hold, with a more positive attitude towards risk-taking, and a capacity to innovate anticipated future trends. Creativity plays an important role in human resource management, as artists and creative professionals can think laterally. Moreover, new jobs requiring new skills created in the post-crisis economy should be supported by labour mobility to ensure that people are employed wherever their skills are needed.

\section{Critical Review of Literature and Creative Industries in Vietnam}

In the early 1990s, Vietnam started to study four key technological areas: information technology, biotechnology, new materials and automation. The target was to generate strong enough technological engines to ensure strong competitiveness of key products which would serve as the core of national industrialization and modernization. However, the number of successful businesses in the four areas remain limited. Bkis, formally known as the Internet Security Center of Hanoi University of Science and Technology, discovered internet software loopholes in well-known businesses such as Toshiba and Google, and tracked attacks against important governmental computer systems in the USA and South Korea. Its' Bkav software holds a significant share in the domestic market.

2008 was a landmark year for Vietnam's biotechnology, as the British Council introduced the concept of biotechnology in the "Creative City". However, four years later, biotechnology remained a new concept to Vietnam, even to administrators, intellectuals, businesses, and creators, not to mention the public. Experts have concerns about what will allow Vietnam to become known for its' creative economy. Vietnam is globally known for its Pho 24, green tea, coffee, and rice. A number of years ago, the Vietnamese technology circle heavily promoted made in Vietnam computer such as: CMC, Sing PC, Mekong Green, Vincaom, $\mathrm{T} \& \mathrm{H}$, Robo, or Elead. Unfortunately, most of these companies failed or their market share was too small for Vietnamese people to recognize. Although it might be impossible to imagine that Vietnam may talented creators as Bill Gates or Mark Zuckerberg, there should still be a more dynamic technology market to allow for technological breakthrough that originate in Vietnam. Data from countries with under US\$1000/capita/year income in an industrialized period, shows that transaction growth in the technology market should be higher than GDP growth. For example, China whose transaction growth in its technology market has doubled GDP growth in the past twenty years.

Vietnam spends about US\$10-15 billion a year on finished products, equipment and spare parts, which makes up $15 \%$ of the national import turnover; the technological content of these 
International Journal of Innovation, Creativity and Change. www.ijicc.net Volume 7, Issue 5, 2019

imported products remains limited. According to project developers in the technology market, Vietnam only imports equipment and complete technology lines, and they do not place proper interest in intellectual assets. About $90 \%$ of imported technologies are at medium and low levels. Technology investment and innovation remains low in Vietnamese businesses, with it making up $0.2-0.3 \%$ of revenue, this proportion is $5 \%$ in India and $10 \%$ in South Korea.

Through the implementation of the FDI attraction strategy, the expectation of receiving high technology and source technology would seem to be distant. Technologies applied in FDI businesses are mainly used ones in their native countries. The number of registered transferred technologies between main companies and their branches is much lower in comparison with existing FDI businesses. In American, Western European and Japanese FDI projects, technology transfers are mostly from regional branches such as South Korea, China, Thailand and Malaysia; only a small number of technologies are regionally advanced. Most FDI businesses manufacture, process and assemble products based on available designs and technologies. More noticeably, FDI businesses are rarely seen to organize their research and development in Vietnam.

Generally, Vietnam's creative industries are not clearly identified because there are no specific statistics available. Nevertheless, some can be directly named and have considerable strength, these being design, arts, education, tourism, performing arts, fashion, handicrafts, culture, foods, etc. Vietnam is considered a new opportunity centre in the world, it provides the great advantages of cross-geographical, cultural and linguistic elements. However, its position is still somewhere towards the bottom of global rankings using different indices, which is partially caused by Vietnamese enterprises' traditional thought of "slavery outsourcing". When Vietnamese enterprises dare to compete in higher segments they will probably create greater value and obtain higher global rankings.

Vietnam currently has four fundamental types of businesses: those develop based on using resources; those that develop based on speculation and short-run operations; those that develop based on cheap labour forces; and those that develop based on creativity. In the $21^{\text {st }}$ century, any country wishing to break out and become prosperous has to base their rise on creative businesses. High technology is essential for a sustainable economy and it is a strategic key for economic growth in countries possessing source technologies like the US, Japan, Russia, EU, etc. As a follower, Vietnam has more than 20 years of development with the slogan "get a short cut, be the leader", but its high technology still remains modest. The Vietnamese Ministry of Science and Technology even admits that Vietnam lags quite far behind other countries in this respect. 
International Journal of Innovation, Creativity and Change. www.ijicc.net Volume 7, Issue 5, 2019

Ninety percent of Vietnam's businesses are small or medium sized, and most of them are industrial, commercial and service ones. They are mostly outsourcing businesses that are not high value adds. Sadly, the technology used by these businesses is mostly 3-4 generations behind what is current. A reviewing of 11 industries in the Vietnamese Ministry of Science and Technology concluded that the general level of industries is at medium, lower medium, and low level as compared to others in the region and the world. There exists a significant technological gap between Vietnam and developed countries. According to a Ministry report, Vietnam's software industry capacity is about US\$140,000/person/year, which is very far behind other countries. In the manufacturing industry, low-tech production accounts for $60 \%$ of the total, while high-tech production accounts for $20 \%$. The contribution of high-tech products and services to GDP is only $5.73 \%$ and $2.12 \%$ respectively, which is quite low.

Vietnam does not have any national policies or strategies on the areas detailed above; as a result, big cities like Hochiminh City, Binh Duong, and Hanoi have to study and create their creative industries by themselves and in their own ways. The localization of creative industries makes programs such as "Creative Saigon", which launched in 2010. Apart from the absence of such policies, the limited connections between businesses and creators in Vietnam is a great obstacle to the formulation and development of creative industries in Vietnam.

As per the literature context, numerous studies have focused on the creative industries and related indicators. Tao, Ho, Luo, and Sheng (2019) have examined the agglomeration effect on the creative industries and their productivity factors. Their empirical analysis investigated firm level data, and found that density elasticity of productivity is 0.31 . Whereas, in those industries which are titled as creative, urbanization is the key source of agglomeration. Digital access, and other factors like the convenience of transport, have a spill over effect which causes an increase in the urbanization of economies.

Zheng and Chan (2014) investigated the impact of creative industry clusters on development in Shanghai. They observed that unchanged cultural policies play a role in restraining creativity. Maryunani and Mirzanti (2015) examined the creative industry and its role in the development and growth in developed economies. To obtain a better understanding, economic growth and financial development, in any country or region, cannot be ignored (ERATAŞ SÖNMEZ \& SAĞLAM, 2017; Fedderke \& Bogetic, 2006; Kamran et al., 2016; Kamran, Mohamed-Arshad, \& Omran, 2019; Rother, 1999; Wu, Jeon, \& Luca, 2010). During the last decade, Li \& Wang (2006) investigated the relationship between the creative industry and economic growth. Whereas, Barrowclough and Kozul-Wright (2008) provided an empirical contribution by defining the connection between the creative industry and 
International Journal of Innovation, Creativity and Change. www.ijicc.net

Volume 7, Issue 5, 2019

economic outcomes in developing economies. In addition, similar trends are examined by (Chaston, 2008).

\section{Research Methodology}

For an empirical investigation of the relationship between the creative industry indicators and economic and financial sector dynamics, this study has collected secondary data. For this purpose, various online sources of creative industry indicators are observed. In addition, for the data collection of economic and financial sector indicators, data bases of the World Bank group (world development indicator) are considered. After the collection of the data, this study has conducted robust multiple regression analysis which helped to explore the impact of creative industry indicators on economic and financial sector dynamics. Robust multiple regression helps to generate unbiased coefficients with a minimum level of risk in terms of standard error. This approach helps to analyse the actual and error free impact of key explanatory variables on the outcome variables of the study. For a better understanding, the following equations are developed and empirically tested under results and discussion.

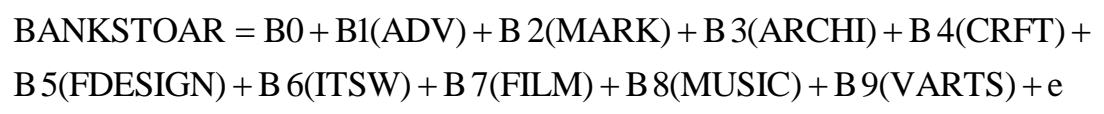

\section{Equation 1}

INTRSPREAD $=\mathrm{B} 0+\mathrm{B}(\mathrm{ADV})+\mathrm{B} 2(\mathrm{MARK})+\mathrm{B} 3(\mathrm{ARCHI})+\mathrm{B} 4(\mathrm{CRFT})+$ B 5(FDESIGN) + B 6(ITSW) + B 7(FILM $)+$ B 8(MUSIC) + B 9 (VARTS $)+e$

\section{Equation 2}

$\mathrm{STOCKTRDE}=\mathrm{B} 0+\mathrm{B} 1(\mathrm{ADV})+\mathrm{B} 2(\mathrm{MARK})+\mathrm{B} 3(\mathrm{ARCHI})+\mathrm{B} 4(\mathrm{CRFT})+$ B 5(FDESIGN) + B 6(ITSW) + B 7(FILM $)+$ B 8(MUSIC) + B 9 (VARTS $)+e$

\section{Equation 3}

$$
\begin{aligned}
& \mathrm{LIR}=\mathrm{B} 0+\mathrm{B} 1(\mathrm{ADV})+\mathrm{B} 2(\mathrm{MARK})+\mathrm{B} 3(\mathrm{ARCHI})+\mathrm{B} 4(\mathrm{CRFT})+ \\
& \mathrm{B} 5(\mathrm{FDESIGN})+\mathrm{B} 6(\mathrm{ITSW})+\mathrm{B} 7(\mathrm{FILM})+\mathrm{B} 8(\mathrm{MUSIC})+\mathrm{B} 9(\mathrm{VARTS})+\mathrm{e}
\end{aligned}
$$

\section{Equation 4}

$\mathrm{DIR}=\mathrm{B} 0+\mathrm{B} 1(\mathrm{ADV})+\mathrm{B} 2(\mathrm{MARK})+\mathrm{B} 3(\mathrm{ARCHI})+\mathrm{B} 4(\mathrm{CRFT})+$ B $5($ FDESIGN $)+$ B $6($ ITSW $)+B$ 7 (FILM $)+$ B $8($ MUSIC $)+$ B $9($ VARTS $)+e$

\section{Equation 5}

$$
\begin{aligned}
& \mathrm{BMGRWOTH}=\mathrm{B} 0+\mathrm{B}(\mathrm{ADV})+\mathrm{B} 2(\mathrm{MARK})+\mathrm{B} 3(\mathrm{ARCHI})+\mathrm{B} 4(\mathrm{CRFT})+ \\
& \mathrm{B} 5(\text { FDESIGN })+\mathrm{B} 6(\mathrm{ITSW})+\mathrm{B} 7(\mathrm{FILM})+\mathrm{B} 8(\text { MUSIC })+\mathrm{B} 9(\text { VARTS })+\mathrm{e}
\end{aligned}
$$

\section{Equation 6}

$\mathrm{INF}=\mathrm{B} 0+\mathrm{B} 1(\mathrm{ADV})+\mathrm{B} 2(\mathrm{MARK})+\mathrm{B} 3(\mathrm{ARCHI})+\mathrm{B} 4(\mathrm{CRFT})+$ $\mathrm{B} 5($ FDESIGN $)+\mathrm{B} 6($ ITSW $)+\mathrm{B} 7($ FILM $)+\mathrm{B} 8($ MUSIC $)+\mathrm{B} 9($ VARTS $)+\mathrm{e}$

\section{Equation 7}


International Journal of Innovation, Creativity and Change. www.ijicc.net

Volume 7, Issue 5, 2019

GROSSCAPITALFOR $=\mathrm{B} 0+\mathrm{B}(\mathrm{ADV})+\mathrm{B} 2(\mathrm{MARK})+\mathrm{B} 3(\mathrm{ARCHI})+\mathrm{B} 4(\mathrm{CRFT})$

+ B $5($ FDESIGN $)+$ B 6(ITSW $)+$ B 7(FILM $)+$ B $8($ MUSIC $)+$ B 9 (VARTS $)+e$

\section{Equation 8}

$\mathrm{EXPGSGDP}=\mathrm{B} 0+\mathrm{B} 1(\mathrm{ADV})+\mathrm{B} 2(\mathrm{MARK})+\mathrm{B} 3(\mathrm{ARCHI})+\mathrm{B} 4(\mathrm{CRFT})+$

B 5(FDESIGN) + B 6(ITSW $)+$ B 7(FILM $)+$ B 8(MUSIC $)+$ B 9(VARTS $)+e$

\section{Equation 9}

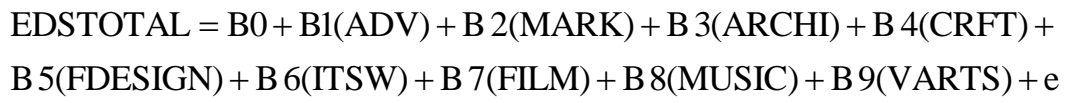

\section{Equation 10}

$\mathrm{GDPGR}=\mathrm{B} 0+\mathrm{B} 1(\mathrm{ADV})+\mathrm{B} 2(\mathrm{MARK})+\mathrm{B} 3(\mathrm{ARCHI})+\mathrm{B} 4(\mathrm{CRFT})+$

B 5(FDESIGN) + B 6(ITSW) + B 7(FILM) + B 8(MUSIC) + B 9(VARTS $)+e$

\section{Equation 11}

$\mathrm{FDI}=\mathrm{B} 0+\mathrm{B} 1(\mathrm{ADV})+\mathrm{B} 2(\mathrm{MARK})+\mathrm{B} 3(\mathrm{ARCHI})+\mathrm{B} 4(\mathrm{CRFT})+$

B 5(FDESIGN) + B 6(ITSW $)+$ B 7(FILM $)+$ B 8(MUSIC) + B 9 (VARTS $)+e$

\section{Equation 12}

GDPCAPITA $=$ B0 + B1 $($ ADV $)+$ B 2 $($ MARK $)+$ B 3 $($ ARCHI $)+$ B 4(CRFT $)+$

B 5(FDESIGN) + B 6(ITSW) + B 7(FILM $)+$ B 8(MUSIC) + B 9 (VARTS $)+e$

\section{Equation 13}

$$
\begin{aligned}
& \mathrm{GNI}=\mathrm{B} 0+\mathrm{B} 1(\mathrm{ADV})+\mathrm{B} 2(\mathrm{MARK})+\mathrm{B} 3(\mathrm{ARCHI})+\mathrm{B} 4(\mathrm{CRFT})+ \\
& \mathrm{B} 5(\mathrm{FDESIGN})+\mathrm{B} 6(\mathrm{ITSW})+\mathrm{B} 7(\mathrm{FILM})+\mathrm{B} 8(\mathrm{MUSIC})+\mathrm{B} 9(\mathrm{VARTS})+\mathrm{e}
\end{aligned}
$$

\section{Equation 14}

Equations 1-4 consider the first four dynamics of the economy and financial sector, while Equations 5-8 considers economy and financial sector indicators from five to eight. Equations 9-14 identify the impact of creative industry indicators for the remaining six factors of the economy and financial sectors in Vietnam. Detail for each of the selected variables is provided under the following section.

\section{Results and Discussion}

The present section has provided empirical discussion on the analysis of the various factors under the title of creative industry and their economic and financial impact. For measuring the creative industry overall, nine factors were considered and explained. To measure the economy and financial sector, 14 indicators were considered. Table 1 predicts the effects of the factors of creative industries and their influence on the economy. To represent the economy of Vietnam, Table 1 shows bank capital to asset ratio (BNKCTOAR), interest rate spread (INTSPREAD), stock trade (STOCKTRDE), and lending interest rate (LIR). The first factor of the creative industry is advertisement (ADV), which shows a negative but insignificant influence on the four outcome variables of the economy and financial sector. This means that the effects of ADV on the first four measures of the economy and financial 
International Journal of Innovation, Creativity and Change. www.ijicc.net Volume 7, Issue 5, 2019

sector, under regression models 1-4, are adversely but insignificantly effected. Such impacts have no effect on the decision-making processes of government officials when integrating the ADV and economic measures. Through Marketing (MARK), the effect on all four measures is significantly positive. This shows that the more there is marketing related activities in Vietnam, the more there is a positive impact on banking capital ratio, interest rate spread, stock trade and lending interest in the economy. Architecture (ARCHI), showed that the more there is construction related activities in the region of Vietnam, the more there is a positive and highly significant influence on the value of BANKCTOAR, and LIR; there was only a significant and positive impact on INTRSPREAD and STOCKTRDE. The highest effect was observed on BNKCTOAR with a coefficient of 7.658 and a standard error of 3.055.

The effects of creative industry factors like craft (CRFT), are found to be significantly positive for BNKCTOAR, while they were found to be insignificant for the remaining economic and financial sector indicators, as presented in Table 1. Fashion design (FDESIGN) showed a highly significant and direct impact on the value of interest rate spread and stock trade in Vietnam. This implies that the contribution of creative industry, through FDESIGN, directs the influence on 2-3 indicators of the economy and financial sectors. The impact of information technology and software (ITSW) on the first two measures of the economy and financial sector is negatively insignificant, whereas STOCKTRADE and LIR have shown coefficients of .382 and 5.882 respectively. This shows that there is a positive and significant influence (only for LIR) by ITSW in Vietnam. Additionally, factors like FILM, MUSIC, and visual arts (VARTS) have shown an insignificant impact on the first four measures of the economy and financial sector.

Table 1: Creative Industries and their Impact on Economy and Financial Sector

\begin{tabular}{|l|l|l|l|l|}
\hline & $(1)$ & $(2)$ & $(3)$ & $(4)$ \\
\hline VARIABLES & BNKCTOAR & INTRSPREAD & STOCKTRDE & LIR \\
\hline ADV & -6.187 & -4.824 & -8.74 & -3.916 \\
\hline & $(4.903)$ & $(5.008)$ & $(4.16)$ & $(3.905)$ \\
\hline MARK & $8.06 \mathrm{e}-10^{*}$ & $1.0254^{* * *}$ & $0.367 * *$ & $4.99 * * *$ \\
\hline & $(4.21 \mathrm{e}-10)$ & $(0.258)$ & $(0.125)$ & $(1.50)$ \\
\hline ARCHI & $7.658^{* *}$ & $1.031^{*}$ & $8.38^{* *}$ & $1.066^{* *}$ \\
\hline & $(3.055)$ & $(.532)$ & $(3.98)$ & $(.389)$ \\
\hline CRFT & $0.367^{*}$ & 0.671 & 3.654 & 6.574 \\
\hline & $(0.197)$ & $(1.024)$ & $(2.365)$ & $(4.365)$ \\
\hline FDESIGN & 5.68 & $0.696 * * *$ & $0.918 * *$ & 4.355 \\
\hline & $(3.85)$ & $(0.154)$ & $(0.367)$ & $(3.45)$ \\
\hline ITSW & $-1.05 \mathrm{e}-06$ & $-7.03 \mathrm{e}-10$ & 0.382 & $5.882^{* * *}$ \\
\hline & $(1.58 \mathrm{e}-06)$ & $(1.77 \mathrm{e}-09)$ & $(2.082)$ & $(1.302)$ \\
\hline FILM & 6.326 & 4.092 & 59.97 & 4,164 \\
\hline
\end{tabular}


International Journal of Innovation, Creativity and Change. www.ijicc.net Volume 7, Issue 5, 2019

\begin{tabular}{|l|l|l|l|l|}
\hline & $(4.311)$ & $(4.427)$ & $(53.38)$ & $(3,395)$ \\
\hline MUSIC & $-1.82 \mathrm{e}-09$ & -0.967 & 1.258 & $-1.63 \mathrm{e}-09$ \\
\hline & $(1.35 \mathrm{e}-09)$ & $(1.187)$ & $(1.015)$ & $(1.20 \mathrm{e}-09)$ \\
\hline VARTS & 288.3 & 0.375 & 11.66 & 357.1 \\
\hline Constant & $(1,651)$ & $(1.682)$ & $(19.14)$ & $(1,270)$ \\
\hline & $142.909^{* *}$ & 40.33 & 1.070 & 68.11 \\
\hline Observations & $(66.516)$ & $(68.10)$ & $(0.968)$ & $(55.05)$ \\
\hline R-squared & 23 & 23 & 23 & 23 \\
\hline Note: Robust standa) & 0.668 & 0.567 & 0.401 & 0.389 \\
\hline
\end{tabular}

Note: Robust standard errors in parentheses, ${ }^{*} * * \mathrm{p}<0.01, * * \mathrm{p}<0.05, * \mathrm{p}<0.1$

Table 2 reveals the impact of creative industry indicators on the economy and financial sector measures like deposit interest rate (DIR), broad money growth (BMGROWTH), inflation (INF), and gross capital formation (GROSSCAPITALFOR). It shows the effect of ADV on all four measures (Table 2) is negative and significant. The effect of MARK is found to be positively significant during the study period. This means that ADV is negatively, and MARK is positively, influencing on all four measures of the economy and financial sector. Similarly, the effect of O.CRFT is negative and significant on BMGRWOTH while positive and significant on INF. However, with the higher output from ITSW, the impact on inflation is 0.625 , which is significant at $5 \%$ with the standard error of 0.014 . The effect of FILM is a substantial indicator of creative industry on INF, and is highly significant and positive. Additionally, the contribution from MUSIC shows a significant and positive influence on gross capital formation. Visual arts also showned a significant and positive impact on DIR in Vietnam.

Table 2: Creative Industries and their Impact on Economy and Financial Sector

\begin{tabular}{|l|l|l|l|l|}
\hline & $(5)$ & $(6)$ & $(7)$ & $(8)$ \\
\hline VARIABLES & DIR & BMGRWOTH & INF & GROSSCAPITALFOR \\
\hline ADV & $-4.021^{* *}$ & $-1,806^{*}$ & $-0.0171^{* *}$ & $-0.0317^{* * *}$ \\
\hline & $(1.504)$ & $(914.0)$ & $(0.00586)$ & $(0.00961)$ \\
\hline MARK & $0.367^{* * *}$ & $1.54 \mathrm{e}-10^{*}$ & $0.827 * *$ & $0.191 * *$ \\
\hline & $(0.0158)$ & $(7.23 \mathrm{e}-11)$ & $(0.025)$ & $(0.067)$ \\
\hline ARCHI & -0.749 & -90.53 & 0.00264 & 0.00437 \\
\hline & $(0.659)$ & $(467.0)$ & $(0.00278)$ & $(0.00396)$ \\
\hline O.CRFT & -.6874 & $-.291 * * *$ & $1.987 * *$ & 0.052 \\
\hline FDESIGN & $(1.325)$ & $(0.062)$ & $(0.929)$ & $(0.368)$ \\
\hline & 0.368 & .837 & 0.164 & 0.737 \\
\hline ITSW & $(0.195)$ & $(1.632)$ & $(0.368)$ & $(0.163)$ \\
\hline
\end{tabular}


International Journal of Innovation, Creativity and Change. www.ijicc.net

Volume 7, Issue 5, 2019

\begin{tabular}{|l|l|l|l|l|}
\hline & $(8.36 \mathrm{e}-10)$ & $(4.61 \mathrm{e}-07)$ & $(0.014)$ & $(0.008)$ \\
\hline FILM & $4.645^{* *}$ & $1,963^{*}$ & $0.0258^{* * *}$ & $0.0499 * * *$ \\
\hline & $(1.763)$ & $(936.9)$ & $(0.00690)$ & $(0.0123)$ \\
\hline MUSIC & -0.092 & $-1.28 \mathrm{e}-10$ & -0.102 & $0.125 * * *$ \\
\hline VARTS & $(0.125)$ & $(2.16 \mathrm{e}-10)$ & $(0.987)$ & $(0.0258)$ \\
\hline & $0.773^{*}$ & 181.9 & -0.00196 & -0.00342 \\
\hline Constant & $(0.437)$ & $(273.9)$ & $(0.00183)$ & $(0.00293)$ \\
\hline & $93.48 * * *$ & 11.752 & $0.159 * *$ & $0.314 * * *$ \\
\hline Observations & $(17.99)$ & $(9.775)$ & $(0.0568)$ & $(0.0849)$ \\
\hline R-squared & 23 & 23 & 23 & 23 \\
\hline
\end{tabular}

Note: Robust standard errors in parentheses, $* * * \mathrm{p}<0.01, * * \mathrm{p}<0.05, * \mathrm{p}<0.1$

For the remaining six indicators of the economy and financial sector, Table 3 considers their causal relationship with the key factors of creative industry. It is found that ADV is positively and significantly impacting the growth rate of gross domestic product (GDPGR), with a coefficient of 1.132 and standard error of 0.985 respectively. A similar effect is observed through MARK with a coefficient of 1.255 and standard error of 0.956 . This means that both the marketing and architecture factors of creative industry are positively influencing economic and financial sector growth. However, for the remaining factors of the economy and financial sector, their effect is found to be insignificant.

CRFT has shown it is a positive and highly significant influence on foreign direct investment (FDI). This means that the more there is CRFT in Vietnam, the more the attraction for FDI and vice versa. However, the factor of FDSIGN is negatively and significantly effecting the GDP during the sample period of the study. The same case is observed when the effect of ITSW on EDSTOTAL and GDPGR is examined. Meanwhile, FILM shows no influence on any of the creative industry factors under Table 3. Furthermore, MUSIC showed a positive and highly significant influence on EXPGSGDP, EDSTOTAL, and GDPGR respectively. VARTS demonstrated a significant influence of 2.307 on EDSTOTAL.

Table 3: Creative Industries and their Impact on Economy and Financial Sector

\begin{tabular}{|l|l|l|l|l|l|l|}
\hline & $(9)$ & $(10)$ & $(11)$ & $(12)$ & $(13)$ & $(14)$ \\
\hline VARIABLES & EXPGSGDP & EDSTOTAL & GDPGR & FDI & GDPCAPITA & GNI \\
\hline ADV & -1.083 & 8.771 & $1.132 * * *$ & -0.172 & -3.04 & -0.0697 \\
\hline & $(1.068)$ & $(6.035)$ & $(0.985)$ & $(0.343)$ & $(3.202)$ & $(0.321)$ \\
\hline MARK & 1.221 & -0.0680 & $1.255^{* * *}$ & -0.363 & -0.258 & 0022 \\
\hline & $(1.031)$ & $(0.0504)$ & $(0.956)$ & $(0.987)$ & $(0.852)$ & $(0.0125)$ \\
\hline
\end{tabular}


International Journal of Innovation, Creativity and Change. www.ijicc.net

Volume 7, Issue 5, 2019

\begin{tabular}{|l|l|l|l|l|l|l|}
\hline ARCHI & $6.501 * * *$ & -3.41 & $4.712^{* *}$ & 0.126 & 103.1 & -0.0814 \\
\hline & $(1.30)$ & $(2.01)$ & $(1.958)$ & $(0.239)$ & $(221.9)$ & $(0.213)$ \\
\hline CRFT & 0.325 & -.333 & -.963 & $3.65 * * *$ & -.837 & .367 \\
\hline & $(1.025)$ & $(.993)$ & $(1.025)$ & $(1.020)$ & $(1.026)$ & $(1.0367)$ \\
\hline FDESIGN & $1.28 \mathrm{e}-10$ & $-0.398^{* * *}$ & $2.45 \mathrm{e}-05^{* * *}$ & 0.635 & $6.90 \mathrm{e}-11$ & $0.362 * *$ \\
\hline & $(9.19 \mathrm{e}-11)$ & $(0.0494)$ & $(4.31 \mathrm{e}-06)$ & $(0.973)$ & $(0.335)$ & $(0.0258)$ \\
\hline ITSW & $-2.61 \mathrm{e}-07$ & $-4.58^{* *}$ & $0.744 * * *$ & -1.16 & -6.21 & 0.064 \\
\hline & $(4.07 \mathrm{e}-07)$ & $(1.58)$ & $(0.0251)$ & $(1.69)$ & $(5.631)$ & $(1.16)$ \\
\hline FILM & 1.002 & -7.592 & -5.769 & 0.212 & 2.774 & 0.0931 \\
\hline & $(1.90)$ & $(5.015)$ & $(3.815)$ & $(0.299)$ & $(1.53)$ & $(0.267)$ \\
\hline MUSIC & $5.37 \mathrm{e}-05 * * *$ & $0.325 *$ & $3.86 \mathrm{e}-05^{* * *} * 0.364$ & 0.1275 & -0.674 \\
\hline & $(3.31 \mathrm{e}-10)$ & $(0.162)$ & $(1.12 \mathrm{e}-05)$ & $(0.125)$ & $(1.43)$ & $(0.135)$ \\
\hline VARTS & 4.252 & $2.307 *$ & 1.882 & -0.0731 & -53.13 & 0.0568 \\
\hline & $(3.241)$ & $(1.158)$ & $(1.187)$ & $(0.112)$ & $(108.8)$ & $(0.0954)$ \\
\hline Constant & 21.103 & $-1.341^{* * *}$ & $1.995 * * *$ & $6.866 * *$ & 8.446 & $4.10 * * *$ \\
\hline & $(15,727)$ & $(0.025)$ & $(0.042)$ & $(2.471)$ & $(6.214)$ & $(1.796)$ \\
\hline Observations & 23 & 23 & 23 & 23 & 23 & 23 \\
\hline R-squared & 0.235 & 0.685 & 0.157 & 0.698 & 0.734 & 0.428 \\
\hline
\end{tabular}

Note: Robust standard errors in parentheses, *** $\mathrm{p}<0.01, * * \mathrm{p}<0.05, * \mathrm{p}<0.1$

\section{Conclusions and recommendations}

In the era of globalization, Vietnam has been building a base for the development of a creative economy which makes creative industries the core. At present, Vietnam has a young population who receive new ideas quite rapidly, have creativity and a determination for overcoming difficulties. However, it is important to take advantage of the youth and develop a creative economy over the next 10 years. The internet is becoming more universal and Vietnam's economy is more deeply integrated deeply with the world's economy. The initial success of digital content services and industrial businesses can be considered as an opportunity to gain experience and confidence in a creative economy. Sectors of a creative economy are characterized by the absence of the requirements for natural resource exploitation or transport infrastructure, while Vietnam telecommunication infrastructure is quite developed and is able to support creative economy development; these are distinctive features that will help Vietnam integrate into the global economy.

The creative industries contribute 3-5\% to the Vietnam's total GDP. However, according to experts, to exploit its advantages and transform creative industries into an economic mainstay, Vietnam needs to adopt specific macro-economic policies. The creative industries are a general concept in Vietnamese business community. Many sectors, such as the light 
International Journal of Innovation, Creativity and Change. www.ijicc.net

Volume 7, Issue 5, 2019

industry and handicrafts, have used creative industries to create high value products. Vietnam has advantages in the development of creative industries due to abundant labour resources. In recent years, some Vietnamese industries have recorded strong growth thanks to the development of the creative industries, such as the handicrafts, leather, and footwear manufacturing. Vietnam needs to adopt a common policy for the development of creative industries. Creative industries require large resources for research and development. Empirical analyses have provided that creative industry-related indicators are positively and significantly impacting on the economy and financial sector. More specifically, the role of marketing, advertisement, architecture, fashion design, and film are found to be significant and constructive for the economy and financial sectors.

Vietnam's businesses need to select a proper orientation and gain a suitable position in the global creative economy. The creative service sectors of great strength in Vietnam, which are also in need of investment are: design, art, education, tourism, performing arts, fashion, handicraft, culture, and foods. Creativity is high-class product that should be used to well position Vietnam in the global economy. 
International Journal of Innovation, Creativity and Change. www.ijicc.net

Volume 7, Issue 5, 2019

\section{REFERENCES}

Barrowclough, D., \& Kozul-Wright, Z. (2008). Creative industries and developing countries: voice, choice and economic growth: Taylor \& Francis.

Buitrago, Pedro \& Duque, Iván. The Orange Economy: An Infinite Opportunity. Washington, DC: Inter-American Development Bank 2013.

Caves, Richard E. (2000), Creative Industries: Contracts between Art and Commerce, Harvard Univ. Press Description and preview.

Cunningham, Stuart, Ryan, Mark David, Keane, Michael \& Ordonez, Diego (2008), 'Financing Creative Industries in Developing Countries', in Diana Barrowclough and Zeljka Kozul-Wright eds, Creative Industries and Developing Countries: Voice, Choice and Economic Growth, Routledge, London and New York, pp. 65110.

Chaston, I. (2008). Small creative industry firms: a development dilemma? Management Decision, 46(6), 819-831.

DCMS (2006), Creative Industries Statistical Estimates Statistical Bulletin, London, UK: Department of Culture, Media and Sport, retrieved 2007-05-26.

ERATAŞ SÖNMEZ, F., \& SAĞLAM, Y. (2017). FINANCIAL DEVELOPMENT AND ECONOMIC GROWTH: A COMPARATIVE ANALYSIS BETWEEN EURO AREA AND EMERGING-DEVELOPING EUROPE. Balikesir University Journal of Social Sciences Institute, 20(38).

Fedderke, J. W., \& Bogetic, Z. (2006). Infrastructure and growth in South Africa: Direct and indirect productivity impacts of 19 infrastructure measures: The World Bank.

Florida, Richard (2002), The Rise of the Creative Class. And How It's Transforming Work, Leisure and Everyday Life, Basic Books

Gielen, Pascal (2013) "Creativity and other Fundamentalisms". Mondriaan: Amsterdam. Hesmondhalgh, David (2002), The Cultural Industries, SAGE 
International Journal of Innovation, Creativity and Change. www.ijicc.net Volume 7, Issue 5, 2019

Howkins, John (2001), The Creative Economy: How People Make Money From Ideas, Penguin

Kamran, H. W., Chaudhry, N., Murtaza, M. M., Zafar, N., Yousaf, A., \& Nazish, H. (2016). Financial Market Development, Bank Risk with Key Indicators and Their Impact on Financial Performance: A Study from Pakistan. American Journal of Industrial and Business Management, 6(03), 373.

Kamran, H. W., Mohamed-Arshad, S. B., \& Omran, A. (2019). Country Governance, Market Concentration and Financial Market Dynamics for Banks Stability in Pakistan. Research in World Economy, 10(2), 136-146.

Kultur \& Kommunikation for Nordic Innovation Centre (2007),Creative Industries Education in the Nordic Countries.

Landry, Charles; Bianchini, Franco (1995), The Creative City, Demos

Lash, S; Urry, J (1994), Economies of Sign and Space, SAGE

Li, W.-w., \& Wang, H.-m. (2006). Creative Industry Promoting the Changing of the Ways of Economic Growth [J]. China Industrial Economy, 11, 5-13.

Maryunani, S. R., \& Mirzanti, I. R. (2015). The development of entrepreneurship in creative industries with reference to Bandung as a creative city. Procedia-Social and Behavioral Sciences, 169, 387-394.

Nielsén, Tobias (2006), The Eriba Model - an effective and successful policy framework for the creative industries (PDF), The Knowledge Foundation

Nguyễn Anh Tiến (2011), "Việt Nam có nền tảng tốt để xây dụng kinh tế sáng tạo" (Vietnam has a trong foundation to develop a creative economy) retrieved on 29/10/2013 at, http://vef.vn/2011-03-14-viet-nam-co-nen-tang-tot-de-xay-dung-kinh-te-sang-tao.

Parrish, David (2005). T-Shirts and Suits: A Guide to the Business of Creativity, Merseyside ACME.

Pasquinelli, Matteo (2006). "Immaterial Civil War: Prototypes of Conflict within Cognitive Capitalism" (PDF).. In: Lovink, Geert and Rossiter, Ned (eds). MyCreativity 
International Journal of Innovation, Creativity and Change. www.ijicc.net

Volume 7, Issue 5, 2019

Reader: A Critique of Creative Industries, Amsterdam: Institute of Network Cultures, 2007.

Phan Tất Thứ (2013), Đổi Mới và Sáng tạo Trong Kinh Doanh: Một Cách Tiếp Cận Thực Tiễn (Innovation and creativity in business: A practical approach), Proceedings of International Conference "Business in Creative Industries, Hanoi.

Rother, M. P. C. (1999). Explaining the behavior of financial intermediation: Evidence from transition economies: International Monetary Fund.

Tao, J., Ho, C.-Y., Luo, S., \& Sheng, Y. (2019). Agglomeration economies in creative industries. Regional Science and Urban Economics, 77, 141-154.

Towse, Ruth (2002), Book Review of Creative Industries, Journal of Political Economy, 110: 234-237.

The Daily Beast (2011), "Thách thức sáng tạo trong thế kỷ 21" (Creative challenges in the $21^{\text {st }}$ century), retrieved on 29/10/2013 at http://vef.vn/2011-02-02-thach-thuc-sangtao-trong-the-ky-21.

Trần Trọng Thành (2013), Làng Nghề, SME và Công Nghiệp Sáng Tạo (Trade villages, SMEs and creative industries), Proceedings of International Conference "Business in Creative Industries, Hanoi.

UNCTAD (2006), Creative Economy and Industries, a Creative Industries Division pamphlet

UNCTAD (2008), Creative Economy Report. The Challenge of Assessing the Creative Economy: towards Informed Policy Making. Geneva and New York: United Nations. Available at: http://www.unctad.org/creativeeconomy.

UNCTAD (2010), Creative Economy Report 2010. Creative Economy: A Feasible Development Option. Geneva and New York: United Nations. Available at: http://www.unctad.org/creative-economy.

UNESCO, Creative Industries - UNESCO Culture, UNESCO, retrieved 2009-11-24

Van Heur, Bas (2010), Creative Networks and the City: towards a Cultural Political Economy of Aesthetic Production. Bielefeld: Transcript. 
International Journal of Innovation, Creativity and Change. www.ijicc.net Volume 7, Issue 5, 2019

VEF.VN (2011), “Kinh tế sáng tạo - giải pháp cho Việt Nam bật lên?” (Creative economy solution for Vietnam to grow), retrieving on 29/10/2013 at http://vef.vn/2011-0224-viet-nam-lam-gi-de-bat-len-bang-kinh-te-sang-tao-.

Wu, J., Jeon, B. N., \& Luca, A. C. (2010). Foreign bank penetration, resource allocation and economic growth: Evidence from emerging economies. Journal of Economic Integration, 166-192.

Zheng, J., \& Chan, R. (2014). The impact of 'creative industry clusters' on cultural and creative industry development in Shanghai. City, Culture and Society, 5(1), 9-22. 